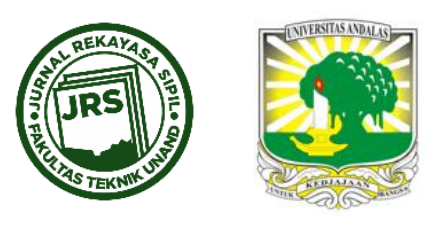

\title{
MODEL PERSAMAAN KERUSAKAN JALAN NAGREG BATAS BANDUNG-GARUT
}

\author{
ANGGA MARDITAMA SULTAN SUFANIR \\ ${ }^{1}$ Dosen Jurusan Teknik Sipil, Politeknik Negeri Bandung(凶angga.mss@polban.ac.id) \\ Naskah diterima : 22 Januari 2018. Disetujui: 12 April 2018. Diterbitkan : 1 Juli 2018
}

\begin{abstract}
ABSTRAK
Jenis perkerasan ruas jalan Nagreg Batas Bandung-Garut merupakan perkerasan lentur dengan jenis kerusakan yang terjadi, yaitu: Alligator cracking, Patching and utility cut patching, dan Potholes. Untuk memproyeksikan kerusakan di masa yang akan datang, guna membantu dalam mempersiapkan biaya pemeliharaan jalan secara jangka panjang perlu diketahui model persamaan kerusakan perkerasan jalannya. Metode yang digunakan untuk mengetahui model persamaan kerusakan jalan yaitu analisis regresi linear berganda menggunakan program Microsoft Excel, dimana persen kerusakan jalan sebagai peubah tidak bebas Y dan kumulatif ESAL per-golongan kendaraan sebagai peubah bebas $\mathrm{X}$, yang masing-masing adalah $\mathrm{X} 1$; X2; X3; X4; X5; X6; X7; X8; dan X9. Proses pemilihan persamaan model kerusakan jalan mengikuti metode analisis langkahdemi-langkah tipe 1, didapat hasil model persamaan tahap ke-7 untuk jenis kerusakan Alligator cracking; tahap ke-8 untuk jenis kerusakan Patching and utility cut patching; tahap ke-8 untuk jenis kerusakan Potholes.
\end{abstract}

Kata kunci : model persamaan kerusakan jalan, persen kerusakan jalan, kumulatif ESAL, analisis regresi linear berganda, analisis langkah-demi-langkah tipe 1

\section{PENDAHULUAN}

Ruas jalan Nagreg Batas Bandung-Garut merupakan jalan nasional tipe 2 lajur 2 arah tak terbagi dengan fungsi jalan arteri primer kelas I dan tata guna lahan pada ruas tersebut yaitu kawasan komersial, kawasan pemukiman, dan kawasan hijau. Ruas jalan tersebut menghubungkan wilayah Kabupaten Bandung dengan wilayah Kabupaten Garut, serta sebagai akses jalan utama dari wilayah barat menuju wilayah timur Pulau Jawa melalui Jalur Selatan. Jenis perkerasan eksisting merupakan perkerasan lentur dengan jenis kerusakan yang terjadi, yaitu: Alligator cracking, Patching and utility cut patching, dan Potholes.

Penelitian ini menggunakan data hasil survey pada tahun 2016 dengan tujuan untuk mengetahui model persamaan kerusakan perkerasan jalan pada Ruas Jalan Nagreg Batas Bandung-Garut KM Bdg 40+100 s/d KM Bdg 42+430. Model persamaan kerusakan jalan dapat digunakan untuk memproyeksikan kerusakan di masa yang akan datang, guna 
membantu dalam mempersiapkan biaya pemeliharaan jalan secara jangka panjang. Lokasi penelitian ditunjukkan pada Gambar 1.

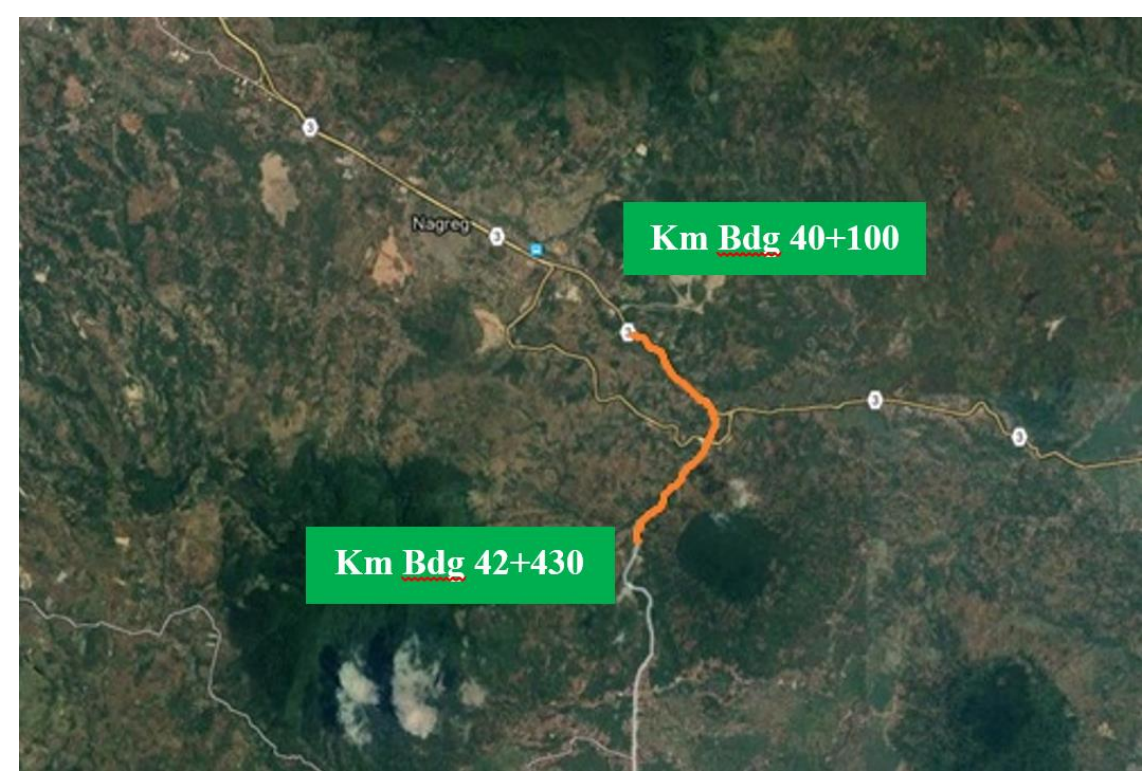

Gambar 1. Lokasi Penelitian pada Ruas Jalan Nagreg Batas Bandung-Garut

(Km Bdg 40+100 s/d Km Bdg 42+430) (sumber: google map)

\section{STUDI LITERATUR}

Kerusakan jalan kadang terjadi lebih dini dari masa pelayanan yang disebabkan oleh faktor alam dan faktor manusia. Faktor-faktor alam yang dapat mempengaruhi mutu perkerasan jalan diantaranya air, perubahan suhu, cuaca, dan temperatur udara. Sedangkan faktorfaktor manusia diantaranya tonase atau muatan kendaraan-kendaraan berat yang melebihi kapasitas dan volume kendaraan yang semakin meningkat. Dari semua faktor tersebut jika terjadi secara terus-menerus akan menyebabkan kerusakan pada jalan yang dilewati (Nugroho E.A., 2013).

Beban berlebih mempengaruhi pengurangan umur rencana perkerasan jalan. Studi kasus pada ruas Jalan Pantura terdapat hubungan antara umur rencana dalam satuan tahun $(\mathrm{Y})$ dan beban berlebih dalam satuan ton $(X)$, yaitu: $Y=-0,127 . X+1,408$ untuk kondisi fatigue dan $\mathrm{Y}=-1,338 . \mathrm{X}+15,75$ untuk kondisi deformasi permanen (Prasetyo A., 2012).

Angka Ekuivalen rencana yang nilainya lebih kecil dari Angka Ekuivalen lapangan menunjukkan bahwa tingkat kerusakan yang ditimbulkan oleh beban kendaraan lebih besar daripada beban rencana, sehingga kerusakan jalan yang terjadi diakibatkan oleh beban lalu lintas (Zunita S.R. dan Hartantyo S.D., 2016).

Semakin besar volume lalu lintas, maka tingkat kerusakan jalan akan semakin bertambah. Studi kasus pada Jalan Aspal Kelas III di Kabupaten Lamongan terdapat hubungan antara volume kendaraan ringan $(\mathrm{X} 1)$, volume kendaraan berat $(\mathrm{X} 2)$, dan nilai kerusakan jalan $(\mathrm{Y})$ yaitu: $\mathrm{Y}=$ 0,022.X1 + 0,001.X2 + 39,88 dengan R2 = 0,85 (Dhana R.R. dan Lubis Z., 2016). 


\section{METODOLOGI PENELITIAN}

\subsection{REGRESI LINEAR BERGANDA}

Menurut Tamin O.Z. 2000, analisis regresi linear berganda adalah metode statistik yang dapat digunakan untuk mempelajari antarsifat permasalahan yang sedang diselidiki. Persamaan regresi linear berganda memiliki lebih dari satu peubah bebas, bentuk umumnya adalah sebagai berikut:

$$
\mathrm{Y}=\mathrm{A}+\mathrm{B} 1 \mathrm{X} 1+\mathrm{B} 2 \mathrm{X} 2+\ldots . .+\mathrm{BNXN}
$$

dengan:

$\mathrm{Y} \quad=\quad$ peubah tidak bebas

$\mathrm{X} 1, \mathrm{X} 2, \mathrm{XN}=$ peubah bebas

$\mathrm{A}, \mathrm{B} 1, \mathrm{~B} 2, \mathrm{BN}=\quad$ konstanta dan koefisien regresi

Koefisien determinasi ganda dinotasikan dengan R2, mempunyai batas limit sama dengan satu (perfect explanation) dan nol (no explanation), nilai antara kedua batas limit ini ditafsirkan sebagai persentase total variasi yang dijelaskan oleh analisis regresi linear berganda. Koefisien korelasi (r) adalah nilai yang menunjukkan kuat/ tidaknya hubungan linear antara peubah tidak bebas dengan peubah bebas antau antara sesama peubah bebas.

Analisis regresi linear berganda digunakan untuk meramalkan bagaimana keadaan (naikturunnya) peubah tidak bebas (kriterium), bila dua atau lebih peubah bebas sebagai faktor prediktor dimanipulasi (dinaik-turunkan nilainya), jadi nilai analisis regresi linear berganda akan dilakukan bila terdapat minimal 2 peubah bebas (Sugiyono, 2010). Untuk analisis regresi linear berganda, jumlah yang disarankan adalah 15-20 sampel per peubah bebas (Hair et al, 2006).

\subsection{ANALISIS LANGKAH-DEMI-LANGKAH TIPE 1}

Metode analisis langkah-demi-langkah tipe 1 secara bertahap mengurangi jumlah peubah bebas sehingga didapatkan model terbaik yang hanya terdiri dari beberapa peubah bebas, prosesnya sebagai berikut:

a. Tahap pertama yaitu menentukan parameter yang akan dijadikan peubah bebas dan peubah tidak bebas, kemudian melakukan uji korelasi untuk mengabsahkan keterkaitannya. Dua persyaratan statistik utama yang harus dipenuhi dalam memilih peubah bebas adalah: peubah bebas harus mempunyai korelasi tinggi dengan peubah tidak bebas, dan sesama peubah bebas tidak boleh saling berkorelasi, jika terdapat dua peubah bebas yang saling berkorelasi, maka pilihlah salah satu yang mempunyai korelasi lebih tinggi terhadap peubah tidak bebasnya.

b. Tahap kedua yaitu melakukan analisis regresi linear berganda dengan semua peubah bebas terpilih untuk mendapatkan nilai koefisien determinasi serta nilai konstanta dan koefisien regresinya.

c. Tahap ketiga yaitu menentukan peubah bebas yang mempunyai korelasi ( $\mathrm{r}$ ) terkecil terhadap peubah tidak bebasnya dan hilangkan peubah bebas tersebut. Kemudian melakukan kembali analisis regresi linear berganda dan mendapatkan kembali nilai koefisien determinasi serta nilai konstanta dan koefisien regresinya.

d. Tahap keempat yaitu melakukan kembali tahap ketiga, satu demi satu sampai hanya tersisa satu peubah bebas saja. 
e. Tahap kelima yaitu mengkaji nilai koefisien determinasi serta nilai konstanta dan koefisien regresi setiap tahap untuk menentukan model terbaik dengan kriteria berikut: banyak peubah bebas yang digunakan, tanda koefisien regresi (+/-) sesuai dengan yang diharapkan, nilai konstanta regresi mendekati nol, nilai koefisien determinasi $\left(\mathrm{R}^{2}\right)$ mendekati satu.

\section{HASIL DAN PEMBAHASAN}

Ruas jalan Nagreg Batas Bandung-Garut KM Bdg 40+100 s/d KM Bdg 42+430 merupakan jalan nasional tipe 2 lajur 2 arah tak terbagi dengan lebar jalan 6 meter. Jenis perkerasan eksisting merupakan perkerasan lentur dengan jenis kerusakan yang terjadi, yaitu: Alligator cracking, Patching and utility cut patching, dan Potholes. Jenis-jenis kerusakan perkerasan jalan diperlihatkan pada Gambar 2.

Data persen kerusakan jalan per-bulan merupakan data sekunder hasil survey yang dilakukan pada tahun 2016. Urutan persen kerusakan tertinggi berdasarkan jenis kerusakannya, yaitu: Patching and utility cut patching, Alligator cracking, dan Potholes. Dalam metode regresi linear berganda, persen kerusakan jalan merupakan peubah tidak bebas (Y) yang nilainya disajikan pada Tabel 1.

Data kumulatif ESAL per-bulan merupakan data sekunder hasil survey yang dilakukan pada tahun 2016. Kendaraan ringan terdiri dari gol.2 sampai dengan gol. 4, sedangkan kendaraan berat terdiri dari gol. 5 sampai dengan gol. 7c. Dalam metode regresi linear berganda, kumulatif ESAL merupakan peubah bebas (X) yang nilainya disajikan pada Tabel 2 .

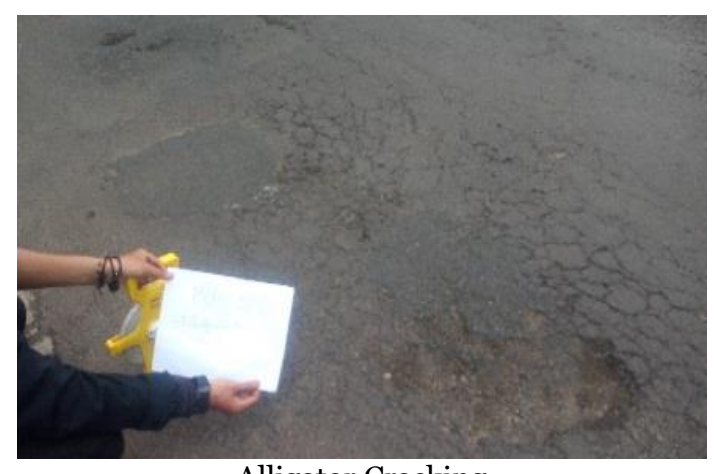

Alligator Cracking

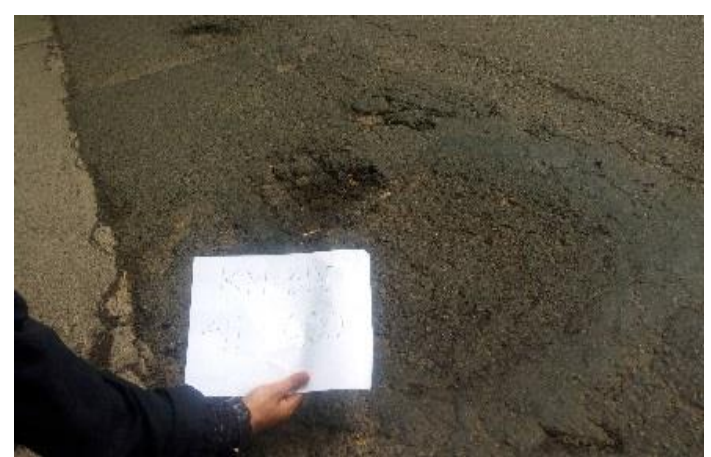

Patching and Utility Cut Patching

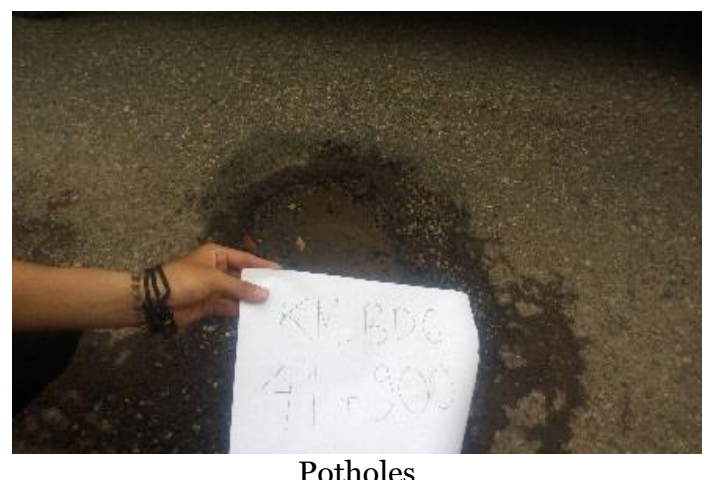

Gambar 2. Jenis Kerusakan Pada Perkerasan Jalan Nagreg Batas Bandung-Garut 
Tabel 1. Data Persen Kerusakan Jalan Pada Tahun 2016

\begin{tabular}{cccc}
\hline $\begin{array}{c}\text { Bulan } \\
\text { ke- }\end{array}$ & \multicolumn{3}{c}{$\begin{array}{c}\text { Persen kerusakan } \\
\text { Patching and utility cut } \\
\text { patching }\end{array}$} \\
\hline 1 & 1.40 & 2.64 & Potholes \\
\hline 2 & 1.50 & 2.64 & 0.16 \\
\hline 3 & 1.62 & 3.96 & 0.21 \\
\hline 4 & 2.10 & 4.03 & 0.28 \\
\hline 5 & 2.22 & 4.36 & 0.35 \\
\hline 6 & 2.25 & 5.72 & 0.40 \\
\hline 7 & 3.20 & 5.78 & 0.40 \\
\hline 8 & 3.56 & 7.18 & 0.47 \\
\hline 9 & 4.87 & 8.20 & 0.55 \\
\hline 10 & 5.43 & 10.36 & 0.63 \\
\hline 11 & 9.16 & 11.94 & 0.75 \\
\hline 12 & 9.38 & 16.40 & 0.80 \\
\hline 13 & 11.00 & 16.89 & 1.40 \\
\hline 14 & 12.40 & 18.73 & 1.56 \\
\hline 15 & 13.90 & 19.04 & 2.96 \\
\hline 16 & 16.15 & 20.19 & 2.45 \\
\hline 17 & 18.37 & 21.46 & 2.61 \\
\hline 18 & 20.47 & 24.12 & 2.96 \\
\hline
\end{tabular}

Sumber: Muhamaddan A.K., 2017

Tabel 2. Data Kumulatif ESAL Pada Tahun 2016

\begin{tabular}{|c|c|c|c|c|c|c|c|c|c|}
\hline \multirow{2}{*}{$\begin{array}{c}\text { Bulan } \\
\text { ke- }\end{array}$} & \multicolumn{9}{|c|}{ Kumulatif ESAL } \\
\hline & Gol. 2 & Gol. 3 & Gol. 4 & Gol. 5 & Gol. 6a & Gol. 6b & Gol. 7a & Gol. 7b & Gol. 7c \\
\hline 1 & 95 & 98 & 225 & 9944 & 3886 & 34664 & 6923 & 853 & 6224 \\
\hline 2 & 115 & 100 & 253 & 10549 & 4370 & 36772 & 7344 & 870 & 6602 \\
\hline 3 & 142 & 111 & 337 & 13284 & 5814 & 42097 & 8407 & 959 & 7558 \\
\hline 4 & 187 & 120 & 446 & 16961 & 9073 & 51863 & 9248 & 1140 & 9312 \\
\hline 5 & 265 & 147 & 631 & 23217 & 16205 & 68584 & 10358 & 1277 & 12314 \\
\hline 6 & 343 & 168 & 1146 & 33989 & 29426 & 80929 & 13697 & 1688 & 17437 \\
\hline 7 & 432 & 195 & 1706 & 41467 & 53433 & 97114 & 19395 & 2390 & 25953 \\
\hline 8 & 552 & 276 & 2539 & 61719 & 97025 & 144545 & 28868 & 3558 & 38629 \\
\hline 9 & 640 & 410 & 3097 & 91863 & 176183 & 215141 & 42967 & 5296 & 57495 \\
\hline 10 & 755 & 611 & 3778 & 136729 & 214944 & 320215 & 63952 & 7882 & 85575 \\
\hline 11 & 906 & 909 & 5624 & 203508 & 319922 & 476609 & 87021 & 9616 & 104402 \\
\hline 12 & 1127 & 1109 & 8371 & 248279 & 476172 & 581463 & 95185 & 11732 & 127371 \\
\hline 13 & 1356 & 1220 & 8596 & 258829 & 480058 & 616127 & 102108 & 13420 & 133973 \\
\hline 14 & 1717 & 1340 & 8933 & 275790 & 485873 & 652899 & 111356 & 14697 & 140197 \\
\hline 15 & 2066 & 1535 & 9564 & 309779 & 494946 & 694995 & 125054 & 15836 & 147755 \\
\hline 16 & 2331 & 1811 & 10710 & 351246 & 548378 & 746858 & 153921 & 16796 & 157067 \\
\hline 17 & 2518 & 1958 & 12415 & 361191 & 724561 & 815442 & 160844 & 17649 & 174504 \\
\hline 18 & 2633 & 2126 & 14954 & 374475 & 821587 & 896371 & 174541 & 18502 & 186819 \\
\hline
\end{tabular}

Sumber: Muhamaddan A.K., 2017

Untuk mengetahui hubungan antara persen kerusakan jalan dengan kumulatif ESAL pergolongan kendaraan, maka dilakukan analisis regresi linear berganda menggunakan program Microsoft Excel. Persen kerusakan jalan sebagai peubah tidak bebas Y, sedangkan kumulatif ESAL per-golongan kendaraan sebagai peubah bebas $\mathrm{X}$, yang masing-masing adalah X1; X2; X3; X4; X5; X6; X7; X8; dan X9. Rekapitulasi analisis regresi linear berganda untuk masing-masing jenis kerusakan jalan disajikan pada Tabel 3. Proses pemilihan model persamaan mengikuti metode analisis langkah-demi-langkah tipe 1 . Untuk jenis kerusakan: Alligator cracking dipilih model persamaan $\mathrm{Y}=0.0017613 \mathrm{X} 1+0.0065657$ 
$\mathrm{X} 2+0.0000008 \mathrm{X} 7+0.6949471$ dan $\mathrm{R}^{2}=0.9941$, Patching and utility cut patching dipilih model persamaan $\mathrm{Y}=0.0000139 \mathrm{X} 6+0.0004358 \mathrm{X} 8+2.7576232$ dan $\mathrm{R} 2=0.9906$, Potholes dipilih model persamaan $\mathrm{Y}=0.0009005 \mathrm{X} 1+0.0001926 \mathrm{X} 2+0.0591730$ dan $\mathrm{R}^{2}$ $=0.9895$. Pemilihan model persamaan berdasarkan nilai koefisien regresi yang positif, nilai R2 yang cukup tinggi, dan nilai intersep tidak begitu banyak berbeda dengan model kombinasi lain.

Tabel 3. Rekapitulasi Hasil Analisis Regresi Linear Berganda per-jenis Kerusakan Jalan

\begin{tabular}{|c|c|c|c|c|c|c|c|}
\hline \multicolumn{8}{|l|}{ Alligator cracking } \\
\hline \multirow[t]{2}{*}{ Peubah } & \multirow{2}{*}{$\begin{array}{l}\text { Tanda yang } \\
\text { diharapkan }\end{array}$} & \multirow{2}{*}{$\begin{array}{c}\text { Parameter } \\
\text { model }\end{array}$} & \multicolumn{5}{|c|}{ Tahap ke- } \\
\hline & & & 1 & 2 & 3 & 4 & 5 \\
\hline Intersep & $+1-$ & c & 0.7548613 & 0.3867115 & 0.5213800 & 0.7697600 & 0.7879325 \\
\hline Kum. ESAL Gol. 2 & + & $\mathrm{X}_{1}$ & 0.0053367 & 0.0046667 & 0.0017981 & 0.0012787 & 0.0024868 \\
\hline Kum. ESAL Gol. 3 & + & $\mathrm{X}_{2}$ & -0.0128727 & 0.0013009 & 0.0060427 & 0.0063091 & 0.0044601 \\
\hline Kum. ESAL Gol. 4 & + & $\mathrm{X}_{3}$ & -0.0004558 & -0.0003398 & 0.0000918 & 0.0001815 & -0.0001099 \\
\hline Kum. ESAL Gol. 5 & + & $\mathrm{X}_{4}$ & -0.0000313 & -0.0000413 & -0.0000450 & -0.0000221 & - \\
\hline Kum. ESAL Gol. 6a & + & $\mathrm{X}_{5}$ & 0.0000142 & 0.0000009 & -0.0000009 & 0.0000017 & 0.0000060 \\
\hline $\begin{array}{l}\text { Kum. ESAL Gol. } \\
6 \mathrm{~b}\end{array}$ & + & $\mathrm{X}_{6}$ & 0.0000447 & 0.0000327 & 0.0000115 & 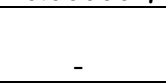 & 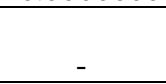 \\
\hline Kum. ESAL Gol. 7a & + & $\mathrm{X}_{7}$ & 0.0001672 & 0.0000587 & 0.0000475 & 0.0000400 & -0.0000030 \\
\hline Kum. ESAL Gol. 7b & + & $\mathrm{X}_{8}$ & -0.0000125 & -0.0007923 & - & - & - \\
\hline Kum. ESAL Gol. 7c & + & $\mathrm{X}_{9}$ & -0.0001556 & - & - & - & - \\
\hline & & $\mathrm{R}^{2}$ & 0.9991 & 0.9984 & 0.9972 & 0.9968 & 0.9948 \\
\hline
\end{tabular}

\begin{tabular}{|c|c|c|c|c|c|c|}
\hline \multirow[t]{2}{*}{ Peubah } & \multirow{2}{*}{$\begin{array}{l}\text { Tanda yang } \\
\text { diharapkan }\end{array}$} & \multirow{2}{*}{$\begin{array}{l}\text { Parameter } \\
\text { model }\end{array}$} & \multicolumn{4}{|c|}{ Tahap ke- } \\
\hline & & & 6 & 7 & 8 & 9 \\
\hline Intersep & $+/-$ & $\mathrm{c}$ & 0.7019434 & 0.6949471 & 0.8110422 & 0.7861062 \\
\hline Kum. ESAL Gol. 2 & + & $\mathrm{X}_{1}$ & 0.0019293 & 0.0017613 & - & - \\
\hline Kum. ESAL Gol. 3 & + & $\mathrm{X}_{2}$ & 0.0049934 & 0.0065657 & 0.0095064 & 0.0087634 \\
\hline Kum. ESAL Gol. 4 & + & $\mathrm{X}_{3}$ & 0.0002305 & - & - & - \\
\hline Kum. ESAL Gol. 5 & + & $\mathrm{X}_{4}$ & - & - & - & - \\
\hline $\begin{array}{l}\text { Kum. ESAL Gol. } \\
6 \mathrm{a}\end{array}$ & + & $\mathrm{X}_{5}$ & - & - & - & - \\
\hline $\begin{array}{l}\text { Kum. ESAL Gol. } \\
6 \mathrm{~b}\end{array}$ & + & $\mathrm{X}_{6}$ & - & - & - & - \\
\hline $\begin{array}{l}\text { Kum. ESAL Gol. } \\
\text { 7a }\end{array}$ & + & $\mathrm{X}_{7}$ & -0.0000011 & 0.0000008 & -0.0000090 & - \\
\hline $\begin{array}{l}\text { Kum. ESAL Gol. } \\
7 \mathrm{~b}\end{array}$ & + & $\mathrm{X}_{8}$ & 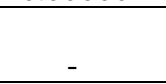 & 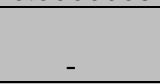 & 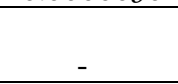 & - \\
\hline $\begin{array}{l}\text { Kum. ESAL Gol. } \\
7 \mathrm{c}\end{array}$ & + & $\mathrm{X}_{9}$ & - & - & - & - \\
\hline & & $\mathrm{R}^{2}$ & 0.9945 & 0.9941 & 0.9929 & 0.9928 \\
\hline
\end{tabular}

\begin{tabular}{|c|c|c|c|c|c|c|c|}
\hline \multicolumn{8}{|c|}{ Patching and utility cut patching } \\
\hline \multirow[t]{2}{*}{ Peubah } & \multirow{2}{*}{$\begin{array}{l}\text { Tanda yang } \\
\text { diharapkan }\end{array}$} & \multirow{2}{*}{$\begin{array}{l}\text { Parameter } \\
\text { model }\end{array}$} & \multicolumn{5}{|c|}{ Tahap ke- } \\
\hline & & & 1 & 2 & 3 & 4 & 5 \\
\hline Intersep & $+/-$ & $\mathrm{c}$ & 2.5475167 & 2.5985597 & 2.7437550 & 2.4378329 & 2.8737023 \\
\hline Kum. ESAL Gol. 2 & + & $\mathrm{X}_{1}$ & 0.0023691 & - & - & - & - \\
\hline Kum. ESAL Gol. 3 & + & $\mathrm{X}_{2}$ & -0.0009943 & 0.0051391 & - & - & - \\
\hline Kum. ESAL Gol. 4 & + & $\mathrm{X}_{3}$ & 0.0011934 & 0.0015801 & 0.0015998 & 0.0014934 & 0.0007360 \\
\hline Kum. ESAL Gol. 5 & + & $\mathrm{X}_{4}$ & 0.0000075 & 0.0000076 & 0.0000121 & -0.0000206 & -0.0000088 \\
\hline Kum. ESAL Gol. 6a & + & $\mathrm{X}_{5}$ & -0.0000105 & -0.0000160 & -0.0000115 & -0.0000162 & - \\
\hline $\begin{array}{l}\text { Kum. ESAL Gol. } \\
\text { 6b }\end{array}$ & + & $\mathrm{X}_{6}$ & $0 \Omega 0$ & $-0 \Omega r>$ & $=00000054$ & 60 & -0.0000023 \\
\hline Kum. ESAL Gol. 7a & + & $\mathrm{X}_{7}$ & -0.0000719 & -0.0000959 & -0.0000540 & -2.00000 & - \\
\hline
\end{tabular}




\begin{tabular}{|c|c|c|c|c|c|c|c|}
\hline \multicolumn{8}{|c|}{ Patching and utility cut patching } \\
\hline \multirow[t]{2}{*}{ Peubah } & \multirow{2}{*}{$\begin{array}{l}\text { Tanda yang } \\
\text { diharapkan }\end{array}$} & \multirow{2}{*}{$\begin{array}{c}\text { Parameter } \\
\text { model }\end{array}$} & \multicolumn{5}{|c|}{ Tahap ke- } \\
\hline & & & 1 & 2 & 3 & 4 & 5 \\
\hline Kum. ESAL Gol. 7b & + & $\mathrm{X}_{8}$ & -0.0000026 & 0.0001948 & 0.0005133 & 0.0004484 & 0.0007143 \\
\hline Kum. ESAL Gol. 7c & + & $\mathrm{X}_{9}$ & 0.0000660 & 0.0000952 & 0.0000383 & 0.0000373 & 0.0000138 \\
\hline & & $\mathrm{R}^{2}$ & 0.9975 & 0.9971 & 0.9970 & 0.9959 & 0.9946 \\
\hline
\end{tabular}

\begin{tabular}{lcccccc}
\hline \multicolumn{1}{c}{ Peubah } & Tanda yang & Parameter & \multicolumn{4}{c}{ Tahap ke- } \\
\cline { 5 - 7 } & diharapkan & model & 6 & 7 & 8 & 9 \\
\hline Intersep & $+/-$ & & 2.6561557 & 2.6559553 & 2.7576232 & 2.8382280 \\
\hline Kum. ESAL Gol. 2 & + & $\mathrm{X}_{1}$ & - & - & - & - \\
\hline Kum. ESAL Gol. 3 & + & $\mathrm{X}_{2}$ & - & - & - & - \\
\hline Kum. ESAL Gol. 4 & + & $\mathrm{X}_{3}$ & - & - & - & - \\
\hline Kum. ESAL Gol. 5 & + & $\mathrm{X}_{4}$ & -0.0000170 & -0.0000170 & - & - \\
\hline Kum. ESAL Gol. 6a & + & $\mathrm{X}_{5}$ & - & - & - & - \\
\hline Kum. ESAL Gol. 6b & + & $\mathrm{X}_{6}$ & 0.0000183 & 0.0000183 & 0.0000139 & 0.0000232 \\
\hline Kum. ESAL Gol. 7a & + & $\mathrm{X}_{7}$ & - & - & - & - \\
\hline Kum. ESAL Gol. 7b & + & $\mathrm{X}_{8}$ & 0.0005792 & 0.0005781 & 0.0004358 & - \\
\hline Kum. ESAL Gol. 7c & + & $\mathrm{X}_{9}$ & -0.0000002 & - & - & - \\
\hline & & $\mathrm{R}^{2}$ & 0.9909 & 0.9909 & 0.9906 & 0.9896 \\
\hline
\end{tabular}

Potholes

\begin{tabular}{|c|c|c|c|c|c|c|c|}
\hline \multirow[t]{2}{*}{ Peubah } & \multirow{2}{*}{$\begin{array}{l}\text { Tanda yang } \\
\text { diharapkan }\end{array}$} & \multirow{2}{*}{$\begin{array}{l}\text { Parameter } \\
\text { model }\end{array}$} & \multicolumn{5}{|c|}{ Tahap ke- } \\
\hline & & & 1 & 2 & 3 & 4 & 5 \\
\hline Intersep & $+1-$ & $\mathrm{c}$ & 0.0825136 & 0.0926929 & 0.0731540 & 0.0905345 & 0.0966534 \\
\hline Kum. ESAL Gol. 2 & + & $\mathrm{X}_{1}$ & 0.0004784 & 0.0004970 & 0.0006231 & 0.0007600 & 0.0007468 \\
\hline Kum. ESAL Gol. 3 & + & $\mathrm{X}_{2}$ & 0.0021124 & 0.0017205 & 0.0015479 & 0.0012699 & 0.0012617 \\
\hline Kum. ESAL Gol. 4 & + & $\mathrm{X}_{3}$ & 0.0001473 & 0.0001441 & 0.0001244 & 0.0001014 & 0.0001087 \\
\hline Kum. ESAL Gol. 5 & + & $\mathrm{X}_{4}$ & -0.0000021 & -0.0000018 & -0.0000031 & - & - \\
\hline Kum. ESAL Gol. 6a & + & $\mathrm{X}_{5}$ & -0.0000016 & -0.0000012 & -0.0000013 & -0.0000008 & -0.0000009 \\
\hline Kum. ESAL Gol. 6b & + & $\mathrm{X}_{6}$ & -0.0000017 & -0.0000014 & - & - & - \\
\hline Kum. ESAL Gol. 7a & + & $\mathrm{X}_{7}$ & -0.0000197 & -0.0000167 & -0.0000158 & -0.0000174 & -0.0000155 \\
\hline Kum. ESAL Gol. 7b & + & $\mathrm{X}_{8}$ & 0.0000623 & 0.0000838 & 0.0000577 & 0.0000168 & - \\
\hline Kum. ESAL Gol. 7c & + & $\mathrm{X}_{9}$ & 0.0000043 & - & - & - & - \\
\hline & & $\mathrm{R}^{2}$ & 0.9978 & 0.9977 & 0.9976 & 0.9972 & 0.9970 \\
\hline
\end{tabular}

\begin{tabular}{lcccccc}
\hline \multicolumn{1}{c}{ Peubah } & \multirow{2}{*}{$\begin{array}{c}\text { Tanda yang } \\
\text { diharapkan }\end{array}$} & $\begin{array}{c}\text { Parameter } \\
\text { model }\end{array}$ & \multicolumn{5}{c}{ Tahap ke- } \\
\cline { 5 - 7 } & $+/-$ & $\mathrm{c}$ & 0.1090707 & 0.0594145 & 0.0591730 & 0.0545701 \\
\hline Intersep & + & $\mathrm{X}_{1}$ & 0.0008273 & 0.0009413 & 0.0009005 & 0.0010560 \\
\hline Kum. ESAL Gol. 2 & + & $\mathrm{X}_{2}$ & 0.0011847 & -0.0001975 & 0.0001926 & - \\
\hline Kum. ESAL Gol. 3 & + & $\mathrm{X}_{3}$ & 0.0000596 & 0.0000516 & - & - \\
\hline Kum. ESAL Gol. 4 & + & $\mathrm{X}_{4}$ & - & - & - & - \\
\hline Kum. ESAL Gol. 5 & + & $\mathrm{X}_{5}$ & - & - & - & - \\
\hline Kum. ESAL Gol. 6a & + & $\mathrm{X}_{6}$ & - & - & - & - \\
\hline Kum. ESAL Gol. 6b & + & $\mathrm{X}_{7}$ & -0.0000158 & - & - & - \\
\hline Kum. ESAL Gol. 7a & + & $\mathrm{X}_{8}$ & - & - & - & - \\
\hline Kum. ESAL Gol. 7b & + & $\mathrm{X}_{9}$ & - & - & - & - \\
\hline Kum. ESAL Gol. 7c & + & $\mathrm{R}^{2}$ & 0.9967 & 0.9905 & 0.9895 & 0.9890 \\
\hline & & & & & & - \\
\hline
\end{tabular}




\section{SIMPULAN}

Berdasarkan hasil penelitian mengenai hubungan antara persen kerusakan jalan dengan kumulatif ESAL di Ruas Jalan Nagreg Batas Bandung-Garut Km Bdg 40+100 s/d Km Bdg 42+430, maka dapat disimpulkan bahwa model persamaan terbaik dari regresi linear berganda analisis langkah-demi-langkah tipe 1 adalah sebagai berikut:

a. Model persamaan tahap ke-7 untuk jenis kerusakan Alligator cracking dengan peubah bebas kum ESAL Gol 2, kum ESAL Gol 3, dan kum ESAL Gol 7a.

b. Model persamaan tahap ke-8 untuk jenis kerusakan Patching and utility cut patching dengan peubah bebas kum ESAL Gol $6 \mathrm{~b}$ dan kum ESAL Gol $7 \mathrm{~b}$.

c. Model persamaan tahap ke-8 untuk jenis kerusakan Potholes dengan peubah bebas kum ESAL Gol 2 dan kum ESAL Gol 3.

\section{DAFTAR KEPUSTAKAAN}

(1982), Guidelines and Procedures for Maintenance of Airport Pavement, Department of Transportation, USA.

(1990), Tata Cara Penyusunan Pemeliharaan Jalan Kota No. 018/T/BNKT/1990, Direktorat

Pembinaan Jalan Kota, Direktorat Jenderal Bina Marga, Departemen PU, Jakarta.

(2003), Perencanaan Perkerasan Jalan Beton Semen Pd.T-14-2003. Departemen Pekerjaan

Umum, Bina Marga. Jakarta.

(2004), Undang-undang nomor 38 tentang Jalan. Jakarta.

2005), Perencanaan Tebal Lapis Tambah Perkerasan Lentur dengan Metode Lendutan Pd.T05-2005-B. Departemen Pekerjaan Umum, Bina Marga. Jakarta.

(2011), Peraturan Menteri Pekerjaan Umum Republik Indonesia nomor 19/PRT/M/2011 tentang Jalan. Jakarta.

(2017), Jalan Nagreg Batas Bandung-Garut. Tersedia: https://www.google.co.id/maps/@7.029975,107.9091339,13034m/data=!3m1!1e3?dcr=0 [25 Agustus 2017]

Dhana, R.R. dan Lubis, Z. (2016), Pengaruh Jumlah Lalu Lintas terhadap Tingkat Kerusakan Jalan di Jalan Aspal Kelas III A di Kabupaten Lamongan. Jurnal CIVILLa Universitas Islam Lamongan Vol. 1 No. 1, hal. 17-23.

Hair, J.F., W.C. Black, B.J. Babin, R.E. Anderson, R.L. Tatham (2006), Multivariate Data Analysis 6 Ed, New Jersey: Prentice Hall.

Muhamaddan A.K. (2017), Perancangan Peningkatan Ruas Jalan Nagreg Batas Bandung-Garut Km Bdg 40+100 s/d Km Bdg 40+430. Tugas Akhir untuk derajat Sarjana Terapan Teknik Perancangan Jalan dan Jembatan. Jurusan Teknik Sipil, Politeknik Negeri Bandung (tidak dipublikasikan).

Nugroho, E.A. (2013), Pengaruh Jumlah Kendaraan terhadap Kerusakan Jalan Aspal Kelas II di Kabupaten Semarang. Tugas Akhir untuk derajat Sarjana Teknik Sipil. Universitas Negeri Semarang (tidak dipublikasikan).

Prasetyo, A. (2012), Analisa Pengaruh Beban Berlebih terhadap Umur Rencana Perkerasan Jalan menggunakan Nottingham Design Method (Studi Kasus: Ruas Jalan Pantura). Tugas Akhir untuk derajat Sarjana Teknik Sipil. Universitas Muhammadiyah Surakarta (tidak dipublikasikan).

Sugiyono (2010), Metode Penelitian Kuantitatif, Kualitatif dan RND. Bandung: Alfabeta.

Tamin, O.Z. (2000), Perencanaan dan Pemodelan Transportasi edisi kedua. Bandung: ITB, hal. 117130.

Zunita, S.R. dan Hartantyo, S.D. (2016), Hubungan Beban Lalu Lintas terhadap Kerusakan Jalan pada Perkerasan Lentur pada Jalan Panglima Sudirman depan Timbangan. Jurnal CIVILLa Universitas Islam Lamongan Vol. 1 No. 1, hal. 13-16. 